МЕТОДОЛОГІЧНІ ПІДХОДИ ЯК ПІДҐРУНТЯ ПРОФЕСІЙНОЇ ПІДГОТОВКИ МАЙБУТНІХ УЧИТЕЛІВ ДО ЗДІЙСНЕННЯ ФАСИЛІТАЦІЙНОЇ ВЗАЕМОДІЇ З УЧНЯМИ

\title{
METHODOLOGICAL APPROACHES AS A BASIS FOR PROFESSIONAL TRAINING OF FUTURE TEACHERS TO FACILITATION INTERACTION WITH STUDENTS
}

Стаття присвячена одній із актуальних проблем у професійній освіті - визначенню методологічних підходів як підгрунтя підготовки майбутніх учителів до здійснення фрасилітаційної взаємодії з учнями. Проаналізовано теоретичні основи проблеми підготовки майбутніх учителів до здійснення фрасилітаційної взаємодії $з$ учнями. На основі аналізу наукових праць методологічними засадами дослідження профресійноі підготовки майбутніх учителів до здійснення фрасилітаційної взаємодії з учнями визначено провідні положення системного, синергетичного, компетентнісного, особистісно-діяльнісного, суб'єктного, акмеологічного та ресурсного підходів. Доведено, що системний підхід сприяє встановленню взаємозв'язків компонентів професійної підготовки майбутніх учителів до здійснення фрасилітаційної взаємодії з учнями, створюючи цим умови для досягнення позитивних результатів; синергетичний підхід надає можливість з'ясування суті самореалізації як базової категорії професійної підготовки майбутніх учителів до фрасилітаційної взаємодії з учнями, що суттєво впливає на розвиток особистості майбутнього вчителя та рівень ссрормованості готовності до цього виду діяльності; компетентнісний підхід має на меті виконувати відповідні професійні та соціальні фрункції, практично вирішувати різні види виробничих завдань; особистісно-діяльнісний підхід доводить, що саме у процесі професійної підготовки майбутні учителі опановують нові форми, методи та засоби фрасилітаційної взаємодії з учнями, враховуючи індивідуальні можливості кожного; суб'єктний підхід мотивує до опанування майбутніх учителів різними способами розкриття внутрішнього потенціалу в діяльності до фрасилітаційної взаємодії з учнями; акмеологічний збільшує здатність особистості до самореалізації, самостановлення, саморегуляції, самоорганізації; ресурсний підхід сприяє нарощуванню потенціалу майбутніх учителів до збагачення новими сенсами, иінностями, змінами його потреб. Перспективи подальших досліджень вбачаємо у розробиі системи підготовки майбутніх учителів до здійснення фрасилітаційної взаємодії 3 учнями на засадах системного, синергетичного, компетентнісного, особистіснодіяльнісного, суб'єктного, акмеологічного та ресурсного підходів.
Ключові слова: професійна підготовка майбутні вчителі, методологічні підходи, фрасилітаційна взаємодія, учні.

The article is devoted to one of the current problems in vocational education - the definition of methodological approaches as a basis for training future teachers to implement facilitation interaction with students. Theoretical bases of the problem of preparation of future teachers for realization of facilitation interaction with pupils are analyzed. Based on the analysis of scientific works, the leading positions of systemic, synergetic, competence, personal-activity, subject, acmeological and resource approaches are determined by the methodological bases of research of professional training of future teachers to carry out facilitation interaction with students. The study proved that: a systematic approach helps to establish the relationship between the components of professional training of future teachers to facilitate interaction with students, thus creating the conditions for achieving positive results; synergetic approach provides an opportunity to clarify the essence of selfrealization as a basic category of professional training of future teachers for facilitation interaction with students, which significantly affects the development of the future teacher's personality and the level of readiness for this activity; the competence approach aims to perform the relevant professional and social functions, to practically solve various types of production tasks personal-activity approach proves that it is in the process of professional training that future teachers master new forms, methods and means of facilitation interaction with students, taking into account the individual capabilities of each; the subjective approach motivates future teachers to master different ways of revealing the inner potential in the activity to facilitate interaction with students; acmeological increases the individual's ability to self-realization, self-formation, selfregulation, self-organization; resource approach helps to build the potential of future teachers to enrich with new meanings, values, changes in its needs. We see prospects for further research in the development of a system of training future teachers to implement facilitation interaction with students on the basis of systemic, synergistic, competency, personality-activity, subject, acmeological and resource approaches.

Key words: professional training, future teachers, methodological approaches, facilitation interaction, students.
Постановка проблеми у загальному вигляді. Професійна підготовка майбутніх учителів до здійснення фрасилітаційної взаємодії 3 учнями передбачає вибір теоретико-методологічних стратегій дослідження. Методологія дослідження ґрунтується на комплексі наукових ідей, що відображають не тільки рівень володіння нау- ковцем фундаментальними істинами, теоріями, принципами, а і сповідувану глобальну фрілософсько-світоглядну позицію.

Сутність методології можна сорормулювати як основні положення, реалізація яких є підґрунтям для здійснення професійної підготовки майбутніх учителів до здійснення фасилітаційної взаємодії 3 
учнями, а методологія педагогіки - це учіння про педагогічні знання, процеси їх набування, способи пояснення (створення концепції) та практичного застосування з метою перетворення або вдосконалення розробленої системи професійної підготовки майбутніх учителів до здійснення фасилітаційної взаємодії з учнями.

Актуальним є питання обґрунтування саме тих методологічних підходів, які сприяють еорективній професійній підготовці майбутніх учителів до здійснення фасилітаційної взаємодії з учнями.

Ознайомлення з результатами досліджень вчених і практичного досвіду професійної підготовки майбутніх учителів спонукають до визначення саме таких методологічних підходів, що будуть концептуальними засадами передумови здійснення фасилітаційної взаємодії з учнями.

Аналіз останніх досліджень і публікацій. Теоретичне обґрунтування питання методології досить складне, оскільки в сучасній науковій літературі немає певних конкретних алгоритмів розкриття основних положень тієї або іншої проблеми. Методологія (від грец. methodos - шлях дослідження, logos - навчання) відповідно до визначення фрілософського енциклопедичного словника $€$ системою принципів і способів організації й побудови теоретичної та практичної діяльності [16, с. 359]. Проведений аналіз наукових досліджень дав підстави стверджувати, що М. Васильєва, обґрунтовуючи методологічні підходи у наукових дослідженнях, взяла за основу загальнофрілософський, загальнонауковий і конкретнонауковий рівні, а також методологічну рефрлексію (застосування дослідником способів наукового пізнання, в яких інтегруються всі джерела методологічного забезпечення) [8], інші ж, зокрема, Л. Рибалко [12], методологічні засади розкривають не на підставі характеристики рівнів методології, бо вони досить часто переплітаються, а шляхом розкриття суті методологічних підходів. Необхідність визначення методологічних підходів в аспекті підготовки майбутніх учителів до фасилітаційної взаємодії з учнями зумовлена тим, що у процесі фрасилітаційної взаємодії фрормуються нові стосунки між суб'єктами (вчителями, учнями та батьками), що дозволяє реалізувати нові соціальні ролі й передати різні види інфрормації. Фасилітація - провідний механізм професійного становлення майбутнього вчителя, оскільки у профрорієнтаційному трикутнику «хочу ↔ можу треба» фрасилітація є механізмом «спроби власних сил» майбутнього учителя [3].

Виділення не вирішених раніше частин загальної проблеми. Обґрунтування та визначення на основі методологічних підходів ролі фасилітаційної взаємодії з учнями у підготовці майбутніх учителів у процесі профресійної підготовки у контексті нашого дослідження дають під- стави дотримуватися другої тенденції, а саме розроблених положень вченої Л. Рибалко.

Мета статті - визначити методологічні підходи, які сприяють ефрективній професійній підготовці майбутніх учителів до здійснення фрасилітаційної взаємодії з учнями.

Виклад основного матеріалу. Методологічними засадами дослідження професійної підготовки майбутніх учителів до здійснення фрасилітаційної взаємодії з учнями вважаємо провідні положення системного, синергетичного, компетентнісного, особистісно-діяльнісного, суб'єктного, акмеологічного та ресурсного підходів.

Системний підхід. Період 70-х рр. XX ст., так званий «системний рух» або «системний бум» у педагогіці, тобто період експансії системного підходу на всі галузі педагогічного знання завершився офрормленням самостійної галузі знань системології, або загальної теорії систем. Ідеї системного підходу до вивчення складних об'єктів, що розвиваються, викладені у працях І. Блауберга, Е. Юдіна та ін. [18].

Ф. Корольов показав, що педагогічні явища належать до складних систем і мають такі особливості, як цілісність (підпорідкованість усіх частин складної системи загальній меті); вплив змін одного параметру на всі інші; необхідність наукового обґрунтування керівництва такими системами [5].

В. Якунін виокремлює характеристики педагогічних систем, а саме: за походженням педагогічна система $є$ реальною; за субстанціональною ознакою - соціальною; за рівнем складності - складною, за характером взаємодії із середовищем відкритою; за ознакою мінливості - динамічною; за способом детермінації - ймовірнісною; за наявністю цілей - цілеспрямованою; за ознакою керованості - самокерованою [19, с. 6]. На високих рівнях організації педагогічна система «вписується» у систему соціуму, соціальних відносин, систему праці, профресії, власного життя особистості, відповідно до чого Б. Ломов розрізняє розвиток педагогічної системи шляхом зміни її організації - по вертикалі та ступеня організованості (зміни в межах конкретної якості) - по горизонталі [7].

Метою системного підходу є пізнання та перетворення складних соціальних систем, зокрема педагогічних, а завданнями - орієнтація уваги дослідника на виявлення наукових знань про закономірності розвитку системи, розробку методів дослідження і конструювання складних за організацією об'єктів і систем, вивчення якостей об'єктів, розкриття цілісності об'єктів, зокрема педагогічних, прогнозування розвитку системи.

Дослідження проблеми професійної підготовки майбутніх учителів до здійснення фрасилітаційної взаємодії з учнями в певній системі передбачає вивчення зазначеної проблеми з позиції більш складного цілісного - встановлення взаємозв'язків 
компонентів профресійної підготовки майбутніх учителів до здійснення фрасилітаційної взаємодії 3 учнями, на основі яких можна змінювати, координувати, упорядковувати зв'язки між частинами, створюючи цим умови для досягнення позитивних результатів.

Синергетичний підхід. Новим міждисциплінарним науковим напрямом, що ґрунтується на ідеях системності та цілісності світу, наукових уявленнях людини про неї і саму себе в цьому світі, $€$ синергетика - теорія самоорганізації. Щодо використання синергетичного підходу в педагогічних дослідженнях, то серед науковців і практиків існують як прихильники, так і опоненти упровадження його в педагогіку. Вважаємо, що синергетика є альтернативною формою теоретичного опанування дійсності, а їі положення є цілком прийнятними у вивченні питань розвитку особистості, зокрема у межах нашого дослідження, що зумовлюється розвивальним потенціалом професійної підготовки майбутніх учителів до здійснення фрасилітаційної взаємодії з учнями.

Розвиток особистості в синергетиці пояснюється 3 позицій відкритості, нелінійності, нерівноважності, нестійкості особистості, хаосу як чинника творення, конструктивного механізму еволюції. У процесі взаємодії особистості з навколишнім середовищем відбувається опредметнення / розпредметнення ії сутнісних сил, розвиток потенційних можливостей. Потреби розвитку можуть реалізовуватися лише відкритою системою. Нелінійність особистості забезпечує оптимальний вибір способів розвитку. Розвиток нелінійної системи майже непередбачуваний, кількість його варіантів більше, аніж у лінійних системах. Розвиток відкритих систем, до яких належить особистість, відбувається завдяки нерівноважності, нестійкості, випадковості, які породжують хаос. «Тільки системи, далекі від рівноваги, системи у стані нестійкості здатні спонтанно організовувати себе й розвиватися» [4, с. 57]. Синергетична парадигма передбачає певний рівень діалогу людини з природою, соціумом, самою собою, оскільки за умов нестійкості середовища, невизначеності виникає проблема управління розвитком за умов нелінійного розвитку світу, а суб'єкт має можливості власного вибору найбільш сприятливого шляху. Як зазначають С. Курдюмов і Т. Малінецький, проблема полягає в тому, «як керувати не керуючи, як малим резонансним впливом забезпечити самоуправління» [6].

Фундаментальні положення синергетичного підходу відкривають якісно нові можливості для розуміння та вирішення проблем професійної підготовки вчителя загалом. Професійний та особистісний розвиток педагога, що забезпечується професійною підготовкою, не можна вважати планомірно-поступовим, лінійним, а це зумовлює перебудову професійної картини світу педагога, його ціннісних орієнтації, їх ієрархії.

Провідною синергетичною ідеєю в контексті дослідження $є$ з'ясування суті самореалізації, як базової категорії професійної підготовки майбутніх учителів до здійснення фрасилітаційної взаємодії з учнями, що суттєво впливає на розвиток особистості майбутнього вчителя та рівень сфрормованості готовності до цього виду діяльності.

Особистісно-діяльнісний підхід. Особистісний підхід тлумачиться як ключовий методологічний принцип вивчення, дослідження, організації педагогічного процесу (зі специфічними цілями, змістом, технологіями), орієнтований на розвиток і саморозвиток власне особистісних властивостей індивіда [1, с. 19-20].

Важливим $\epsilon$ сорормульоване В. Рибалкою положення, згідно з яким стверджується, що особистісний підхід дає змогу долати однобічність уявлення про те, що психіка людини розвивається тільки в міру засвоєння надбань людства [11]. Особистість розвивається також і в процесі перетворення суб'єктом дійсності, що оточує її. Головна функція особистості, на думку полягає в тому, що вона сприяє виникненню в людини стійкості й незалежності від безпосереднього впливу середовища і робить її в певному сенсі творцем самої себе і того світу, в якому вона живе [11].

3 наведених положень про особистісний підхід випливає висновок, що його реалізація має ґрунтуватися на науковому уявленні про особистість і їі структуру, у контексті якої стає можливий цілісний розгляд окремих психічних функцій, властивостей, психолого-педагогічних явищ, процесів.

В експериментальному педагогічному дослідженні виключно важливим $€$ поєднання особистісного й діяльнісного підходів, оскільки саме в такий спосіб досягається необхідна цілісність у формуванні особистості. Розвиток особистості відбувається в діяльності.

Як зазначає О. Попова, діяльність є основою, засобом і вирішальною умовою розвитку особистості. 3 іншого, боку, ніяке педагогічне явище, чи $€$ воно процесом, станом або властивістю особистості, що виявляється в діяльності, а тому і саму діяльність з її елементами - діями та вчинками, не можна правильно розуміти без урахування їх особистісної зумовленості. Отже, обидва підходи, особистісний і діяльнісний, $є$ тісно пов'язаними та взаємозумовленими, тому в контексті нашого дослідження доцільно говорити про особистіснодіяльнісний підхід [10, с. 141-142].

Реалізація особистісно-діяльнісного підходу в контексті нашого дослідження передбачає, що саме у процесі професійної підготовки майбутні учителі опановують нові фрорми, методи та засоби фрасилітаційної взаємодії з учнями, враховуючи індивідуальні можливості кожного. 
Суб'єктний підхід. Проблема суб'єктності вчителя стає найважливішим методологічним положенням педагогічної теорії та практики, суть якого полягає у постійному саморозвитку і самовдосконаленні особистості педагога, їх принциповій незавершеності.

У межах дослідження важливим $€$ визнання особистості майбутнього вчителя як суб'єкта педагогічної діяльності, з позиції якої він повноцінно буде реалізовувати творчий потенціал. Основою такої позиції є ідеї С. Рубінштейна про суб'єкт як центр організації буття й суб'єктності, яка виявляється через потребу і здатність людини себе вдосконалювати [14].

3 позиції суб'єкта педагогічної діяльності майбутній учитель має право на звернення до власного «Я», власну реалізацію особистісно-професійних здібностей, вибір тих засобів, що потрібні йому для формування низки компетентостей у процесі фахової підготовки. Внутрішньою умовою його існування є розуміння, сприйняття себе як суб'єкта педагогічної діяльності, а зовнішньою - залучення до процесу педагогічної діяльності. Майбутнього вчителя можна визнати суб'єктом педагогічної діяльності тоді, коли він активно оволодіває різними способами розкриття внутрішнього потенціалу в діяльності до фрасилітаційної взаємодії 3 учнями. У межах цієї вимоги суб'єктом діяльності є нова, перетворена якість особистості, що свідчить про повну перебудову всієї системи її психологічної організації, а не лише про реалізацію здібностей, мети відповідно до потреб.

Компетентнісний підхід. Поняття компетентнісно зорієнтованої освіти прийшло до нас із зарубіжних країн, де воно є широковживаним i дослідженим. Як зазначає Ю. Бойчук, головним стимулом для розвитку зусиль у галузі компетентнісного підходу в освіті стали вимоги бізнесу й підприємництва до кваліфрікованих працівників приймати відповідальні рішення на основі отриманих знань і їх інтеграції [8, с. 189]. Так, дослідження, метою якого було порівняти освітній рівень випускників вищих навчальних закладів Росії, України, Білорусі, США, Франції, Канади й Ізраїлю, проведене у 2004 р. Світовим банком, зафіксувало, що студенти пострадянських країн мають дуже високі показники (9-10 балів) за критеріями «знання» та «розуміння», але низькі (1-2 бали) за критеріями «застосування знань на практиці», «аналіз» і «синтез». Студенти 3 розвинутих країн, маючи відносно невисокий показник за критерієм «знання», демонстрували високий ступінь розвитку навичок за критеріями «аналіз», «синтез» і «застосування знань на практиці» [2]

Також слід ураховувати, що на ринку праці необхідні не самі по собі знання, а здатність фахівця виконувати відповідні професійні та соціальні фрункції, практично вирішувати різні види виробничих завдань.
Особливого значення для нашого дослідження набувають методологічні орієнтири акмеологічного підходу як напряму міждисциплінарних досліджень людини, що виник на межі природничих, суспільних, гуманітарних, технічних дисциплін - інтегративно-комплексної науки акмеології, що вивчає френоменологію, закономірності, механізми розвитку людини на етапі зрілості, досягнення нею найвищих рівнів розвитку. Назва цієї галузі наукового знання походить від давньогрецького терміну «akme»-вершина, розквіт, вища точка розвитку, зрілість і «logos» - учіння про неї, а словосполучення «enakmyeinal» - бути в акме, тобто в повному розквіті, на вищому ступені розвитку.

Як свідчить аналіз змісту словникових дефрініцій, акме $€$ багатомірною характеристикою стану дорослої людини, що пов'язана 3 досягненням найвищих показників у особистісно-соціальному розвитку, професійній діяльності, творчості. Отже, методологічна суть акмеологічного підходу полягає у вивченні «вершинних», ідеальних якостей як у системі життєдіяльності особистості загалом, так і у сорері профресії.

В. Стрельніков обґрунтовує інтенціональнодинамічну модель акме, у якій критерієм виступає не точка, а процес інтенсивного зростання та якісного стрибка розвитку, тобто сутнісними ознаками акме є прогресивна спрямованість (конструктивна інтенція), інтенсивність (лавиноподібний динамізм розвитку), принципова його незавершеність (відкритість до наступного витка розвитку). Така модель акме дає необхідний ключ до продуктивного розуміння освітніх процесів, управління індивідуально-профресійним розвитком, орієнтації на постійне удосконалення і творчий поступ, що за відповідних умов можуть йти безупинно по висхідній траєкторії [15, с. 85-87].

Учена Л. Рибалко [12] характеризує акме як одновершинну і багатовершинну моделі. Поряд із широким поглядом на проблему вершинності розвитку людини акмеологія розглядає акме і більш вузько, як оволодіння людиною професією і досягнення в ній творчих результатів, майстерності. Звідси випливає особливе значення для акмеології кола проблем профресійного становлення. Відзначаючи складність виникаючих проблем і нерозв'язаних питань, учена визнає значущість і перспективність педагогічної акмеології.

На нашу думку, проаналізовані концептуальні положення дозволяють стверджувати про беззаперечну цінність акмеологічного підходу для нашого дослідження, зокрема: акмеологічна спрямованість профресійної підготовки зорієнтована на професійні досягнення педагога, максимальне використання його особистісного і професійного потенціалу, що вплине на рівень готовності майбутніх учителів до здійснення фрасилітаційної взаємодії з учнями; сприяння суб'єкту у віднаходженні 
найбільш оптимального способу дії у конкретній профресійній ситуації ґрунтується на здатності особистості до самореалізації, самостановлення, саморегуляції, самоорганізації, які є ключовими моментами акмеологічного підходу.

Ресурсний підхід. Педагогічна думка концентрує увагу на розвиткові людини, котра, будучи одночасно і фрізичною, і соціальною істотою, не лише вступає в політичні, організаційні й економічні відносини, а й одночасно самовизначається як особистість, тобто стає суб'єктом свого розвитку, що вимагає врахування в освітньому процесі ресурсів, тобто сукупності об'єктивно наявних умов, засобів, необхідних для реалізації конкретних дій особистості в освітньому процесі [9, с. 167]. Деякі вчені займаються дослідженням ресурсного підходу в системі освіти, зокрема Т. Цецоріна [17] досліджує проблему організації освітнього процесу у школі на основі ресурсного підходу, Т. Рогова [13] - принцип урахування ресурсів особистості як один із принципів персоналізованого підходу, В. Павленко [9, с. 202-205] доводить значущість ресурсно-стильового комплексу методів в управлінні стресовими ситуаціями тощо.

Учений В. Павленко розглядає саму освіту як ресурс розвитку особистості, суспільстваідержави, що втілюється у психолого-педагогічному проектуванні процесу освоєння людського досвіду як сукупності ресурсів освіти людини; у підтримці інноваційної діяльності в конкретних освітніх системах, інвестиціях у галузі освіти; у варіативності освітніх цінностей, цілей, змісту, форм і методів упливу на особистість, які можуть бути за певних умов ресурсом індивіда, суспільства, держави [9, с. 4].

В. Лозова ресурсний підхід у педагогічній науці визначає як сукупність технологій, способів, прийомів забезпечення, виявлення та використання ресурсів і розвитку потенціалів особистості 3 метою підвищення різних видів ії діяльності, організації спілкування та стимулювання до самореалізації [8, с. 180].

Аналіз ідей ресурсного підходу [8; 9; 17] дозволяє уточнити окремі положення стосовно досліджуваної теми: перехід від можливості в реальність $€$ прогресивною зміною, оскільки розширюються можливості самореалізації, і людина може більш повно розкритися. Результатом розвитку особистості $€$ певні новоутворення, що виникають у процесі самореалізації, останні доповнюють ресурси людини, змінюючи й удосконалюючи іï; особистість не так часто і неповною мірою використовує власні потенційні можливості. 3 метою покращення стану справи необхідно створювати умови, які б позитивно впливали на розвиток ресурсів особистості, тобто говориться про професійну підготовку майбутніх учителів до здійснення фрасилітаційної взаємодії з учнями; розкриття й викорис- тання ресурсного потенціалу майбутнього вчителя сприяють сформованості готовності до здійснення фрасилітаційної взаємодії з учнями. Це можна пояснити тим, що у процесі нарощування потенціалу майбутній учитель збагачується новими сенсами, цінностями, змінюється система його потреб. Удосконалення й реалізація педагогічного потенціалу підштовхують майбутнього вчителя до руху вперед, до досконалості у процесі організації фрасилітаційної взаємодії з учнями.

Висновки. На основі аналізу наукових праць методологічними засадами дослідження професійної підготовки майбутніх учителів до здійснення фасилітаційної взаємодії 3 учнями визначено провідні положення системного, синергетичного, компетентнісного, особистісно-діяльнісного, суб'єктного, акмеологічного та ресурсного підходів. Доведено, що: системний підхід сприяє встановленню взаємозв'язків компонентів професійної підготовки майбутніх учителів до здійснення фасилітаційної взаємодії з учнями, створюючи цим умови для досягнення позитивних результатів; синергетичний підхід надає можливість з'ясування суті самореалізації як базової категорії професійної підготовки майбутніх учителів до фрасилітаційної взаємодії з учнями, що суттєво впливає на розвиток особистості майбутнього вчителя та рівень сорормованості готовності до цього виду діяльності; компетентнісний підхід має на меті виконувати відповідні профресійні та соціальні фрункції, практично вирішувати різні види виробничих завдань; особистісно-діяльнісний підхід доводить, що саме у процесі професіійної підготовки майбутні учителі опановують нові фрорми, методи та засоби фасилітаційної взаємодії з учнями, враховуючи індивідуальні можливості кожного; суб'єктний підхід мотивує до опанування майбутніх учителів різними способами розкриття внутрішнього потенціалу в діяльності до фрасилітаційної взаємодії з учнями; акмеологічний збільшує здатність особистості до самореалізації, самостановлення, саморегуляції, самоорганізації; ресурсний підхід сприяє нарощуванню потенціалу майбутніх учителів щодо збагачення новими сенсами, цінностями, змінами його потреб.

Незважаючи на те, що кожен із представлених підходів розкриває сутнісні характеристики явищ, дослідження професійної підготовки майбутніх учителів до здійснення фрасилітаційної взаємодії з учнями не може обмежуватися якимось одним із них.

Перспективи подальших досліджень вбачаємо у розробці системи підготовки майбутніх учителів до здійснення фрасилітаційної взаємодії з учнями на засадах системного, синергетичного, компетентнісного, особистісно-діяльнісного, суб'єктного, акмеологічного та ресурсного підходів. 


\section{БІБЛІОГРАФІЧНИЙ СПИСОК:}

1. Артемов В.Ю. Особистісно-орієнтований підхід та модель світу інфрормаційного аналітика. Педагогічний процес: теорія і практика. 2005. Вип. 2. 215 с.

2. Бондар В.І., Бондар С.П. Компетентнісний підхід до шкільної освіти: мода сучасності чи необхідність? Науковий часопис НПУ ім. М.П. Драгоманова. Серія 17. Теорія і практика навчання та виховання. 2006. Вип. 3. С. 3-10.

3. Галіцан О.А. Теоретичне підґрунтя проблеми застосування принципів педагогічної срасилітації у професійній діяльності вчителя сучасної школи. Науковий часопис НПУ ім. М.П. Драгоманова. Серія 16: Творча особистість вчителя: проблеми теорії $i$ практики. 2012. Вип. 18 (28). С. 129-132.

4. Коробченко А.А. Проблеми особистісно-орієнтованого навчання у вищих навчальних закладах. Збірник наукових праць Бердянського державного педагогічного університету (Педагогічні науки). 2005. № 4. 210 C.

5. Королев Ф.Ф. Системный подход и возможности его применения в психолого-педагогических исследованиях. Советская педагогика. 1970. № 9. C. $103-115$.

6. Курдюмов С.П., Маленецкий С.П. Синергетика-теорияобразования:идеи,методы,перспективы. Москва : Знамя, 1993. 64 с.

7. Ломов Б.Ф. Системный поход и проблема детерминизма в психологии. Психологический журнал. 1989. № 4. С. 19-33.

8. Наукові підходи до педагогічних досліджень : колективна монографрія / за аг. ред. В.І. Лозової. Харків, 2012. 348 с.

9. Павленко В.В. Ресурсно-стильовий комплекс методів управління стресовими ситуаціями. Наука $і$ освіта. 2004. № 6-7. С. 202-205.
10.Попова О.В. Розвиток інноваційних процесів у середніх загальноосвітніх навчально-виховних закладах України в XX столітті : автореф. дис. ... докт. пед. наук : 13.00.01. Харків, 2001. 39 с.

11. Рибалка В.В. Особистісний підхід як психолого-педагогічний принцип організації профрільної та професійної підготовки учнівської молоді. Психологія особистісно орієнтованої профресійної підготовки учнівської молоді : науково-методичний посібник. Київ, Тернопіль : Підручники і посібники, 2002. C. 80-90.

12. Рибалко Л.С. Акмеологічні засади профресійнопедагогічної самореалізації майбутнього вчителя : дис. ... докт. пед. наук. Харків, 2008. 457 с.

13. Рогова Т.В. Розвиток профресійно-педагогічної компетентності вчителя : методичний аспект. Засоби навчальної та науково-дослідної роботи. 2004. Вип. 21. С. 197-206.

14. Рубинштейн С.Л. Бытие и сознание. Человек и мир. Москва - Санкт-Петербург : Питер, 2003. 512 с.

15. Стрельніков В.Ю. Акмеологічна компетентність викладача вищої школи. Вісник Черкаського університету. Серія «Педагогічні науки». 2013. C. 71-74.

16. Философский энциклопедический словарь / редкол. : Аверинцев С.С., Араб-Оглы Э.А., Ильичёв Л.Ф. и др. Москва : Советская энциклопедия, 1989. 815 с.

17. Цецорина Т.А. Организация образовательного процесса в школе на основе ресурсного похода : авторефр. дисс. ... канд. пед. наук : 13.00.01. Белгород, 2002. 23 с.

18. Юдин Э.Г., Блауберг И.В. Становление и сущность системного подхода. Москва : Наука, 1973. $270 \mathrm{c}$.

19. Якунин В.А. Педагогическая психология : учебное пособие. Санкт-Петербург : Полиус, 1998. 639 с. 